\title{
Zero cost conditioning techniques to improve the indoor environment of school buildings
}

\author{
Enrique Larrumbide Gómez-Rubiera (Main Author) \\ Eduardo Torroja Construction Sciences Institute. Higher Council for Scientific Research \\ Calle de Serrano Galvache, 4, 28033 Madrid (Spain) \\ elarrumbide@ietcc.csic.es
}

Jorge Gallego Sánchez-Torija (Corresponding Author)

Department of Construction and Technology in Architecture

Technical School of Architecture of Madrid, Polytechnic University of Madrid

Avda. Juan de Herrera 4, 28040 Madrid (Spain)

jorge.gallego@upm.es

\section{César Bedoya Frutos}

Department of Construction and Technology in Architecture

Technical School of Architecture of Madrid, Polytechnic University of Madrid

Avda. Juan de Herrera 4, 28040 Madrid (Spain)

cesar.bedoya@upm.es

Manuscript Code: 1385

Date of Acceptance/Reception: 26.11.2019/26.03.2019

DOI: $10.7764 /$ RDLC.18.3.525

\begin{abstract}
In order to reduce the use of energy in buildings, it is necessary to make changes in the society paradigm, not only changes in the way buildings use energy. It seems appropriate to analyse the savings that can be obtained by simple actions related to the implementation of good practices for passive conditioning, for which no economic investment are required. As a zero-investment action, the possibility of moving the school schedule to the period of the day in which the exterior temperature is lower needs to use energy to maintain the comfort condition inside the building is analyzed. Simulations of nine activities about moving school schedules and close the shutters in a teaching centre building located on the Spanish climatic zone D3 are carried out. The percentage of savings when the teaching centre imparts classes from 14:00 to 21:00 during October to May and from 7:00 to 14:00 during September closes the shutters in the summer period and in winter evenings is the $50 \%$. The $€ 6,120$ of savings that are obtained annually with this activity could be an interesting economic injection that allows to undertake future investments in the school, and with it achieving the objectives sought with circular economy.
\end{abstract}

Keywords: indoor environmental quality (IEQ); school building; energy optimization; thermal comfort; circular economy

The concept of circular economics was already in use in the 90's to describe a closed system of interaction between economy and environment (Pearce \& Turner, 1990). The European Union is taking the first steps to implement this concept in the field of waste by publishing the (UE) 2018/851 Directive (Unión Europea, 2018), establishing an improvement in waste management in order to protect and preserve the quality of the environment, human health, promoting circular economy principles and improving the use of renewable energy, among other aspects. This directive states, quoting literally, that "a more efficient use of resources would also bring substantial net savings to the European Union companies, public authorities and consumers while reducing total emissions annual greenhouse gases".

Circular economy not only seeks a sustainable production, but a responsible consumption (García, 2018). It attempts to constitute an alternative to the model of linear economy based on the "taken-manufacture-consume and eliminate" sequence, which is based on the hypothesis of abundance, availability, ease of obtaining and cheap disposal of resources (European Commission, 2014).

The current economic model of production and resource management, based on promoting short-term consumption, makes the system truly unstable. For this reason, the circular economy promotes the reduction in consumption, resources being kept as for long as possible in use and recycled at the end of their useful life (de las Heras, 2016). Circular economy seeks to reduce the use of resources, energy and the flow of waste over the life-cycle of products (Li et al., 2010). The role of the park built in the circular economy is crucial because of its environmental impacts. It also 
provides important opportunities for the reduction in energy use, the emission of greenhouse gases and the production of waste (Pomponi \& Moncaster, 2017). Normally the building stock is analysed in terms of energy incorporated to the materials during the construction phase. From the point of view of circular economy, we would also have to wonder about the energy used in buildings through their useful life, as well as investigating what happens once the useful life of the building ends.

A classic point of view used to analyse buildings is the post-occupancy evaluation which considers the effectiveness of occupied environments for humans as users (Zimring \& Reizenstein, 1980). Even though maybe this approach, which has evolved in the analysis of the life cycle of buildings, suffers from thought that the use of energy is produced in buildings. Buildings don't use energy: people do (Janda, 2011). This study delves into this approach, focusing in how the users of the building can, modifying their habits, change the energy activity of the building, progressing to circular economy.

The technical vision, which takes for granted that improvising the energy efficiency of buildings is going to reduce energy consumption, collides with the limitation that if societies are not motivated to conserve energy, there will be no serious progress (Rosa et al., 1988). As Jevons' paradox reminds us, the introduction of more energy-efficient technologies can lead to an increase in total energy consumption (Amado \& Sauer, 2012). If habits are not changed, technical improvements can generate a sense of efficiency that leads to increase consumption.

In order to reduce the use of energy in buildings, it is necessary to make changes in the society paradigm, not only changes in the way buildings use energy. Sometimes, improving the thermal insulation of buildings is an investment difficult to recover (Gallegos, 2018). At other times, strategies to promote more efficient energy management are successfully studied (Torralbo, 2018).

Nothing better than the circular economy as a new social paradigm that promotes a change in the neoliberal lifestyle with an excessive consumption, enabling a rethinking of the human relationship with their environment (Valderrama, 2017).

Royal Decree 56/2016 (Ministerio de Industria, Energía y Turismo, 2016) concerning energy audits is written up as a partial transposition of the European Directive 2012/27/UE (Unión Europea, 2012) on energy efficiency. It aims to contribute to the attainment of the objective of achieving in 2020 a savings of $20 \%$ in the primary energy consumption (European Commission, 2018a) and the targets set for 2030 (European Commission, 2018b) and 2050 (European Commission (2018c) in the European Union.

Energy auditing can become an essential tool when it comes to approaching intervention measures in an existing building, which will save the final energy consumption and reduce $\mathrm{CO}_{2}$ emission to the atmosphere (Lara et al., 2015).

The operational energy audit (Gallego, 2017) provides measures that not costly for the building's agents in the application of energy saving.

The new normative requirements determined by Europe force the member states to follow approaches aimed at minimizing the consumption of non-renewable primary energy, as determined by the Basic Energy Saving document (Ministerio de Fomento, 2013), hereinafter it DB HE.

The energy audit in the building means recording and analysing all the characteristics of the building's envelope, including walls, floors, ceilings, doors, skylights, and windows (Mahdi, 2018). Between the thermal building envelope component that give shape to the building, one of the most sensitive to energy exchange is the window gap (Larrumbide \& Bedoya, 2015) so when proposing saving measures, the thermal behaviour of the window should be studied in detail.

Description of the Problem

When an energy audit is carried out in a building in order to limit the energy losses and gains through its building thermal envelope, the following action measures are studied: the improvement in the window gap, the increase in the insulation of façades, roofs and floors and the treatment of thermal bridges.

To study the economic viability of the action measures in the thermal envelope of the building, the energy audit finds out the investments to be made and the amortization periods of such investments. The high level of investment needed to limit energy losses and gains in the building through the building thermal envelope and the excessive time 
it takes to recover such investment, are a major difficulty in order to carry out such measures.

As an alternative, it is proposed to seek an implication of the users of the teaching centre, so that zero-investment action and adequate passive conditioning measures can help to obtain significant savings in the energy management of the building.

As a zero-investment action, the possibility of moving the school schedule to the period of the day in which the exterior temperature is lower needs to use energy to maintain the comfort condition inside the building.

As a correct measure of passive conditioning it is proposed to make a correct management of the opening and closing of the shutters, both in the winter and summer period.

The aim is to study the interrelationship between the implementation of both measures so that, following the criteria based on the circular economy, demand for resources is has not increased and $\mathrm{CO}_{2}$ emissions are reduced. The savings obtained with the implementation of these measures can be destined to undertake the measures to limit the energy losses and gains in the building through its thermal envelope that otherwise would be unfeasible. With the launching of this circular economy process, it would be able to obtain a Benefit for the environment and for the users of the teaching centre, generating, in addition, new jobs necessary for the implementation of the most ambitious measures.

The study of the behavioural change with respect to natural ventilation is ruled out because it is an individual action that is performed in each classroom. The real effects that these changes produce are difficult to quantify because they depend on a behavior that can vary between different people and in different periods of time.

\section{Methodology}

First of all, the constructive information about the building and its period of occupation are collected.

After that, a model is generated in an energetic simulation program. The Unified Tool Lider Calener (Ministerio de Industria, Energía y Turismo, 2017) is used because this is the program of energetic simulation used to justify the fulfilment of the Spanish regulations regarding the limitation of energy demand and the limitation of energy consumption of the buildings. With this program the data on energy losses and gains are obtained in the different constructive elements of the building envelope for the current use of the building.

Afterwards, three possible actions are raised:

A first activity is the modification of the using schedule of the building, delaying it by two hours. Three interventions are presented in which each one is carried out together with the previous intervention:

- 1.1. Impart classes from 9:00 $\mathrm{h}$ to $16: 00 \mathrm{~h}$.

- 1.2 . Close the shutters in the summer period to protect the building from the energy gains due to the incidence of solar radiation through the windows.

- $\quad$ 1.3. Close the shutters in winter evenings to reduce the energy losses by transmission through the windows.

A second activity is the modification of the schedule, doing the classes in the evening hours.

- 2.1. Impart classes from 14:00 $\mathrm{h}$ to $21: 00 \mathrm{~h}$.

- $\quad$ 2.2. Close the shutters in the summer period to protect the building from the energy gains due to the incidence of solar radiation through the windows.

- $\quad$ 2.3. Close the shutters in winter evenings to reduce the energy losses by transmission through the windows.

A third activity is the correction of the previous schedule. The afternoon schedule is maintained during the months of October to May and the current schedule is maintained during September.

- 3.1. Impart classes from 14:00 h to 21:00 h during October to May and from 7:00 to 14:00 during September.

- $\quad$ 3.2. Close the shutters in the summer period to protect the building from the energy gains due to the incidence of solar radiation through the windows.

- $\quad$ 3.3. Close the shutters in winter evenings to reduce the energy losses by transmission through the windows.

The corresponding simulations of the nine activities are carried out.

In order to obtain the thermal transmittance of the window gap with the effect of the closed shutter, the increase of 
thermal resistance is calculated which implies lowering the shutters, according to the criteria of the UNE EN-ISO 10077-1 (Asociación Española de Normalización y Certificación, 2010; Díaz et al., 2013). Afterwards, a new thermal transmittance $U$ value to the night period is applied and the decrease of transmittance percentage during the day is obtained. This result is the one that is introduced in the calculation tool to obtain the possible reduction in the heating demand.

Finally, we analyse the results obtained and study the possible savings that will occur during the summer and winter periods, subsequently extracted the conclusions of the study.

To assess the economic savings that can be obtained in a year of operation of the building during summer and winter periods, it is considered an efficiency of $80 \%$ for the boiler (Blanco \& Peña, 2006) and 200\% for air conditioning equipment (Ministerio de Industria, Energía y Turismo \& IDAE, 2014). It is worked considering the gas cost $0.05 € / \mathrm{kWh}$ (Ministerio de Energía, Turismo y Agenda Digital, 2018) and the electric supply $0.16 € /$ kWh (EDP energía, 2019).

The ventilation and infiltration rate used in simulations is $7.2 \mathrm{~m}^{3} / \mathrm{hm}^{2}$. Air permeability in windows, with a pressure of $100 \mathrm{~Pa}$ used in simulations is $50 \mathrm{~m}^{3} / \mathrm{hm}^{2}$. Both values have remained constant to analyze only the variables considered in the paper.

On the other hand, when closing the shutters in summer, forces the use of artificial lighting instead of daylight. This study has been carried out by taking into account only energy consumption to overcome the demand for heating and cooling but regardless of electricity consumption. The increase in electricity consumption by turning on the lights due to closing the shutters in summer is much smaller than the energy consumption involved in cooling the space to combat solar radiation. Electricity consumption is not the subject of this paper.

The use of experimental data is discarded because the greater precision it could provide does not significantly influence the results. The results that will be obtained using the same methodology in the different activities allow comparisons between them to be made and conclusions obtained with the sufficient degree of robustness.

\section{Case study}

The case study is carried out in a teaching centre built in 1970 . It has an area of 7,404.37 $\mathrm{m}^{2}$. It has not been rehabilitated energetically. The image of the building introduced in the Unified Tool Lider Calener is detailed in Figure 1.

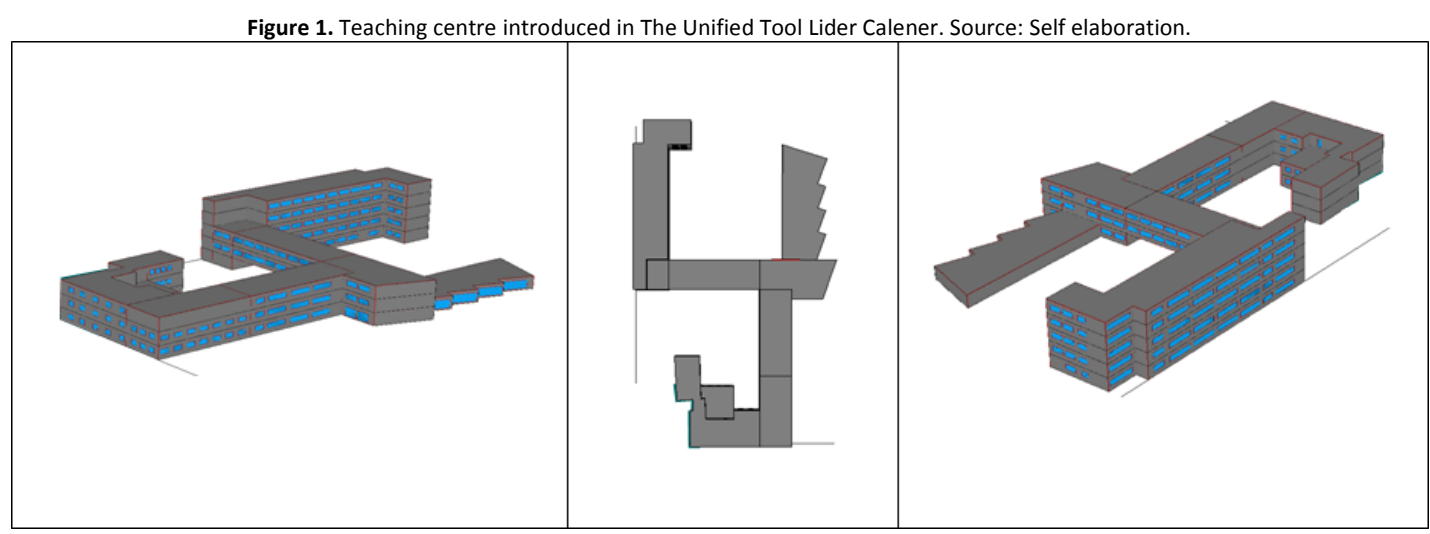

The building has a water heating system with diesel boiler and radiators. It also has a refrigerant cooling system with split air conditioning equipment.

\section{Information}

The thermal transmittance values of the building skin are specified in Table 1.

The building is located on the Spanish climatic zone D3, according to the classification establish in DB HE.

Figure 2 represents the external time-to-year temperatures of the climatic zone. Based on them the period of opening of the teaching centre is overlapped: from 7.00 to 14.00 hours during the months of September to May. The school 
days during June have not been considerate because with the current educational law, during these days' the exams are taking place and the use of the building decreases quite considerably with respect the usual operation.

\begin{tabular}{lc}
\multicolumn{2}{c}{ Table 1. Thermal transmittance of the building skin. Source: Self elaboration. } \\
\hline Constructive element & Thermal transmittance $\left(\mathrm{W} / \mathrm{m}^{2} \cdot \mathrm{K}\right)$ \\
\hline Roof & 0.65 \\
Façade & 0.60 \\
Floor & 2.45 \\
Exterior structure & 1.49 \\
Glass & 5.70 \\
Framework & 5.70 \\
Completed window & 5.70 \\
\hline
\end{tabular}

Figure 2. External time-to-year temperatures in the climatic zone referenced with the overlapping of the opening period of the teaching centre. Source: Self elaboration.

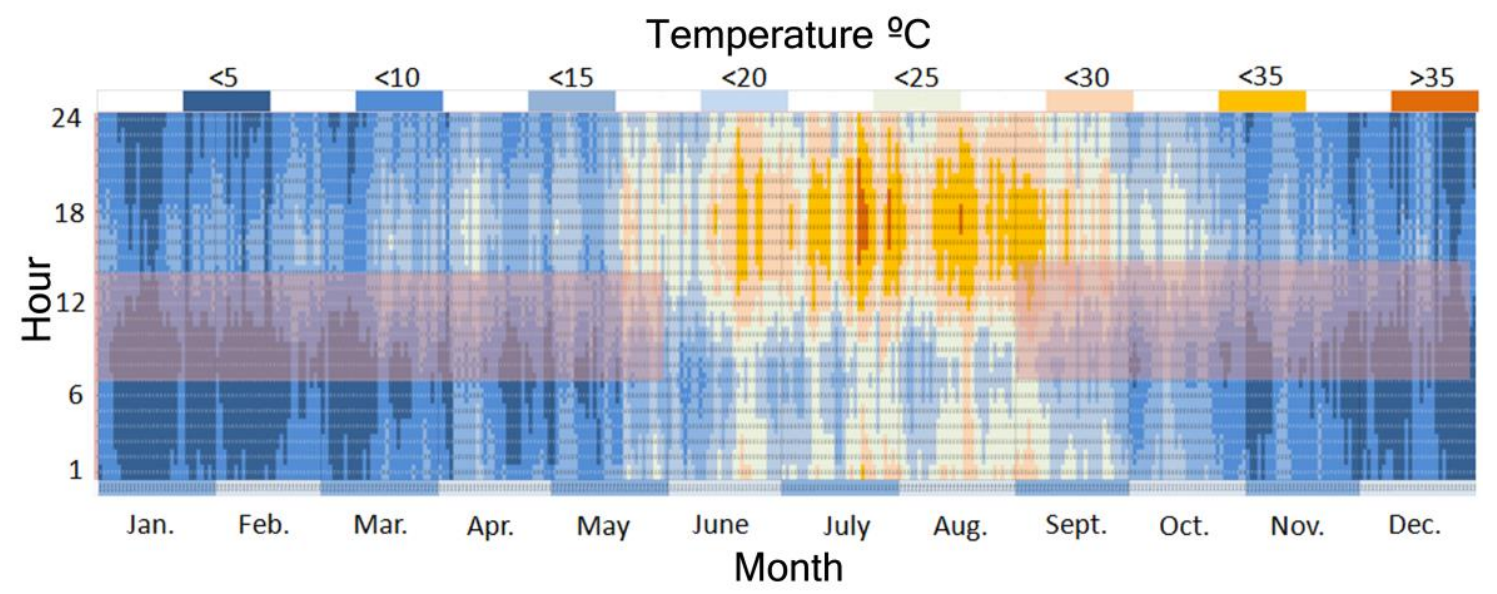

It is appreciated how the highest temperatures are recorded from June to September, in the later hours, while the lowest temperatures are recorded during the dawn and morning hours of November to March. School hours are developed during the coldest temperatures of the year.

The set temperature is defined in DB HE as the temperature or range of temperatures considered in the calculations of the energy demand that set the lower temperature limit from which the conditioning systems of the building operated, requiring energetic contribution.

The maximum and minimum daily outdoor temperatures and the winter and summer temperatures set for the use contemplated in this building are represented in Figure 3. It also represented the starting and ending dates of summer period.

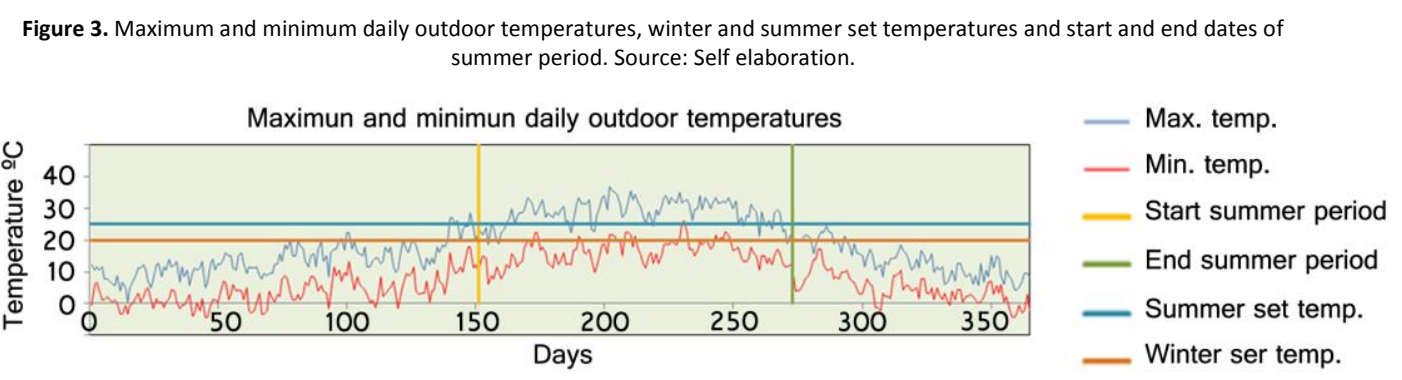

The maximum and minimum daily indoor temperatures inside the building in free fluctuation are represented in figure 4. It also represented winter and summer set temperatures and the start and end dates of the summer period. 
Figure 4. Maximum and minimum daily indoor temperatures of the building in free fluctuation, winter and summer set temperatures and start and end dates of summer period. Source: Self elaboration.
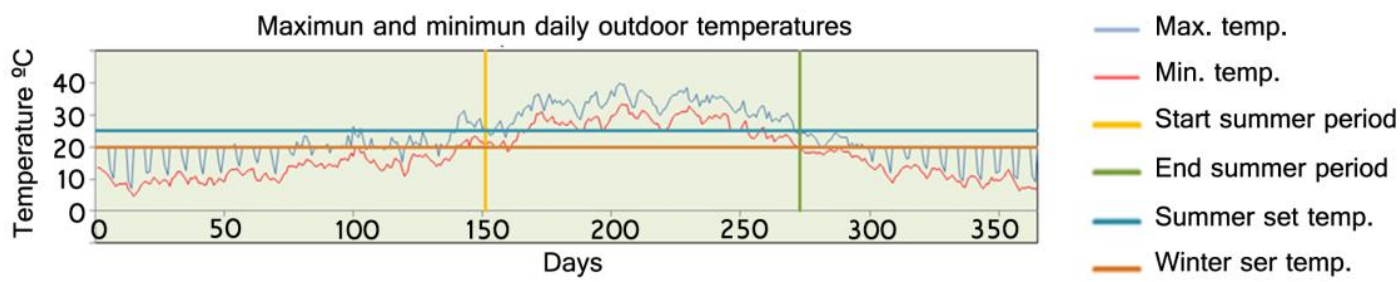

The distribution of energy losses and gains that occur in the different constructive elements of the thermal envelope are represented in Figure 5.

Figure 5. Distribution of energy losses and gains by constructive elements of the thermal envelope for winter and summer periods. Source: Self elaboration.

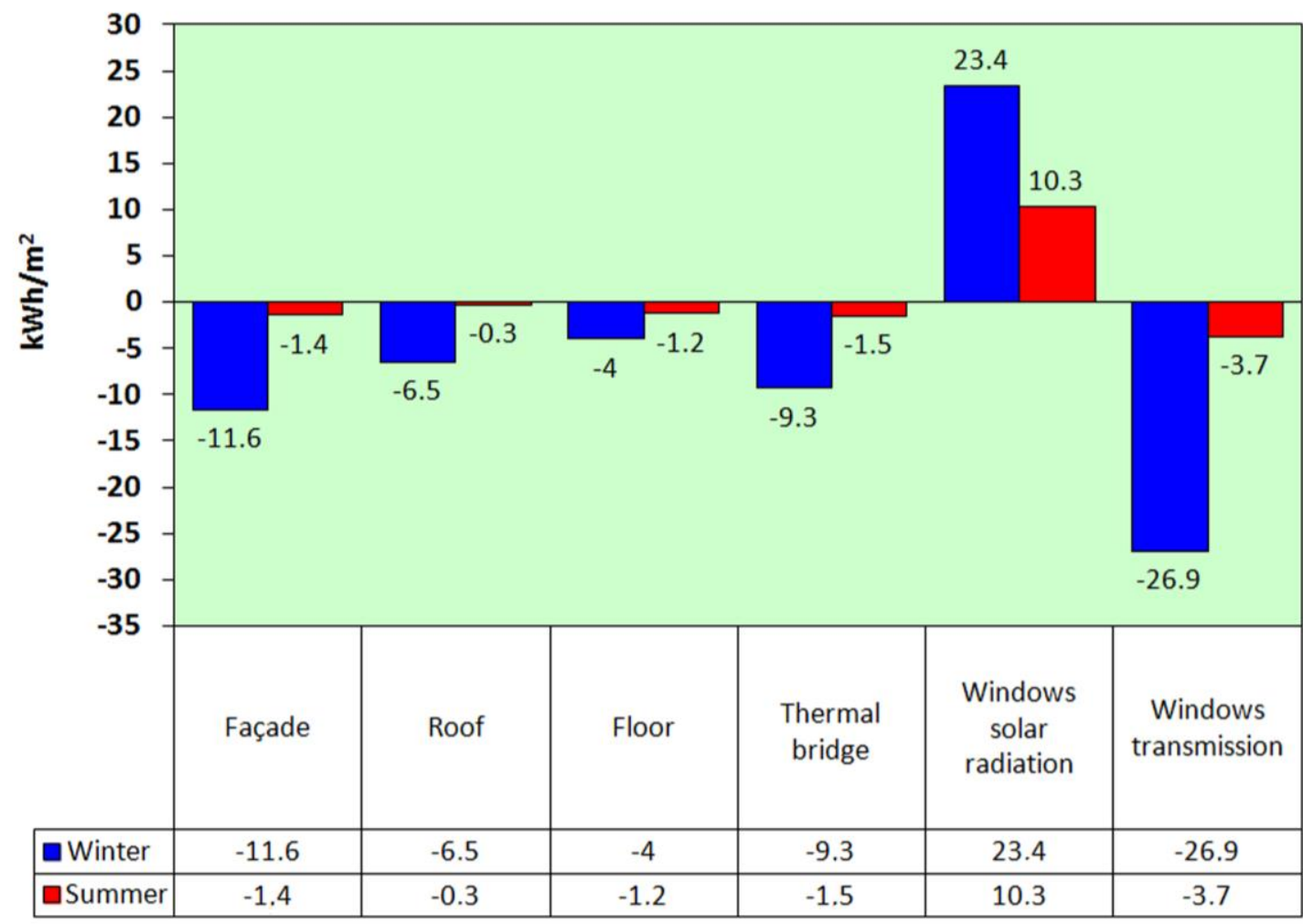

It is observed that the highest losses and gains are take place through the windows.

During the winter time, the energy gain that is produced by solar radiation which penetrated the building through the windows is less than the loss of energy that is produced by transmission through these windows. More energy is lost than is gained in the building' glazing.

In the summer period, during the working hours of the educational centre, the energy gain that is produced by solar radiation which penetrated the building through the windows is higher than the loss of energy that is produced by transmission through the windows. More energy is gained than lost through the building's glazing.

Table 2 shows the result of the energy heating for demand (DH) and cooling (DC) as well as the joint energy demand (DJ), obtained as a weighted sum of the energy demand for heating and cooling just as is indicated on the DB HE. The weighting is carried out according to the consumption of primary energy require to fight each energy demand. The expression which express the joint energy demand for buildings located on peninsular territory is DJ $=D H+0.70 \mathrm{DC}$. It is expressed in $\mathrm{kWh} / \mathrm{m}^{2}$.year. 
Table 2. Heating demand (DC), cooling demand (DR) y combination demand (DG) in different studied actions. Source: Self elaboration.

\begin{tabular}{lccc}
\multicolumn{4}{c}{ Table 2. Heating demand (DC), cooling demand (DR) y combination demand (DG) in different studied actions. Source: Self elaboration. } \\
\hline Activity & $\begin{array}{c}\mathrm{D}_{\mathrm{H}} \\
\left(\mathrm{kWh} / \mathrm{m}^{2} \cdot \text { year }\right)\end{array}$ & $\begin{array}{c}\mathrm{D}_{\mathrm{c}} \\
\left(\mathrm{kWh} / \mathrm{m}^{2} \cdot \text { year}\right)\end{array}$ & $\begin{array}{c}\mathrm{D}_{\mathrm{J}} \\
\left(\mathrm{kWh} / \mathrm{m}^{2} \cdot \text { year}\right)\end{array}$ \\
\hline 0. Classes from 7:00 to 14:00 & 36.3 & 2.8 & 38.26 \\
1.1. Classes from 9:00 to 16:00 & 33.0 & 3.5 & 35.45 \\
1.2. Close shutters on summer + 1.1. & 33.1 & 1.2 & 33.94 \\
1.3. Close shutters on winter nights +1.2. & 27.2 & 1.7 & 28.39 \\
2.1. Classes from 14:00 to 21:00 & 29.3 & 4.7 & 32.59 \\
2.2. Close shutters on summer + 2.1. & 29.3 & 1.9 & 30.63 \\
2.3. Close shutters on winter nights +2.2. & 24.1 & 2.6 & 25.92 \\
3.1. Classes from 14:00 to 21:00 October-May & 29.3 & 3.3 & 31.61 \\
Classes from 7:00 to 14:00 September & & & 30.28 \\
3.2. Close shutters on summer + 3.1. & 29.3 & 1.4 & 25.5 \\
3.3. Close shutters on winter nights +3.2. & 24.1 & 2 & 3 \\
\hline
\end{tabular}

The percentages of savings we have obtained in relation to the initial state with different studied actions are detailed in Table 3.

\begin{tabular}{lccc}
\multicolumn{4}{c}{ Table 3. Percentage of savings obtained in a different studied action. Source: Self elaboration. } \\
\hline Activity & $\begin{array}{c}\text { \% heating } \\
\text { savings }\end{array}$ & $\begin{array}{c}\text { \% cooling } \\
\text { savings }\end{array}$ & $\begin{array}{c}\text { \% combination } \\
\text { savings }\end{array}$ \\
\hline 0. Classes from 7.00 to 14.00 & 0.0 & 0.0 & 0.0 \\
1.1. Classes from 9.00 to 16.00 & -10.0 & 20.0 & -7.9 \\
1.2 Close shutters on summer + 1.1. & -9.7 & -133.3 & -12.7 \\
1.3. Close shutters on winter nights +1.2. & -33.5 & -64.7 & -34.8 \\
2.1. Classes from 14.00 a 21.00 & -23.9 & 40.4 & -17.4 \\
2.2. Close shutters on summer + 2.1. & -23.9 & -47.4 & -24.9 \\
2.3. Close shutters on winter nights +2.2. & -50.6 & -7.7 & -47.6 \\
3.1. Classes from 14.00 to 21.00 October-May & -23.9 & 15.2 & -21.0 \\
Classes from 7.00 to 14.00 September & -23.9 & -100.0 & -26.4 \\
3.2 Close shutters on summer + 3.1. & -50.6 & -40.0 & -50.0 \\
3.3. Close shutters on winter nights +3.2. & & & \\
\hline
\end{tabular}

The economic savings we get in relation to the initial state with different studied actions are shown in Table 4.

\begin{tabular}{lccc}
\multicolumn{4}{c}{ Table 4. Economic savings obtained in different studied actions. Source: Self elaboration. } \\
\hline Activity & $\begin{array}{c}\text { Heating } \\
\text { savings }(€)\end{array}$ & $\begin{array}{c}\text { Cooling } \\
\text { savings }(€)\end{array}$ & $\begin{array}{c}\text { Global } \\
\text { savings }(€)\end{array}$ \\
\hline 0. Classes from 7:00 to 14:00 & 0 & 0 & 0 \\
1.1. Classes from 9:00 to 16:00 & 1,527 & -415 & 1,113 \\
1.2 Close shutters on summer + 1.1. & 1,481 & 948 & 2,429 \\
1.3. Close shutters on winter nights +1.2. & 4,211 & 652 & 4,863 \\
2.1. Classes from 14:00 a 21:00 & 3,239 & $-1,125$ & 2,114 \\
2.2. Close shutters on summer + 2.1. & 3,239 & 533 & 3,773 \\
2.3. Close shutters on winter nights +2.2. & 5,646 & 118 & 5,764 \\
3.1. Classes from 14:00 to 21:00 October-May & 3,239 & -296 & 2,943 \\
Classes from 7:00 to 14:00 September & 3,239 & 829 & 4,069 \\
3.2 Close shutters on summer + 3.1. & 5,646 & 474 & 6,120 \\
3.3. Close shutters on winter nights +3.2. & & & \\
\hline
\end{tabular}


If we analyze Table 3, we found that the activity that obtains a better behaviour is the 3.3, which consider a timetable from 14:00 $\mathrm{h}$ to $21: 00 \mathrm{~h}$ the months of October to May and from 7:00 $\mathrm{h}$ to 14:00 $\mathrm{h}$ during September, with the shutters closed in summer and winter nights. The savings in heating is $50.6 \%$, while the savings obtained in cooling is $40 \%$.

Figure 6 shows graphically the results obtained in heating and cooling demands in different studied action.

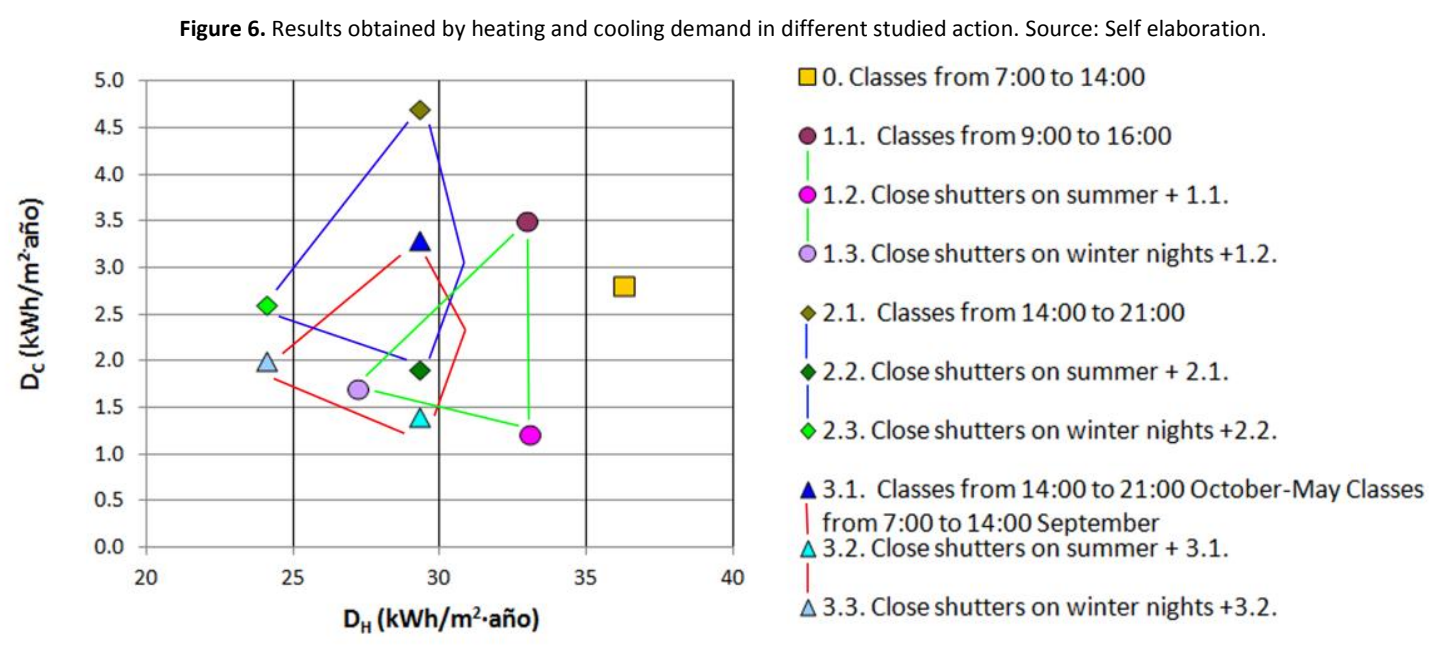

In Figure 6 shows how activities 1.1, 2.1 and 3.1, which consist of zero cost interventions (modification of schedules), but without a passive conditioning (closing the shutters), suppose a worsening of the results obtained in the cooling demand between $15 \%$ and $40 \%$. However, it should be borne in mind that the cooling demand occurs mainly during September. This has a low influence in the overall demand because there building remains without activity during the months of June, July and August.

Figure 6 also shows how activities 1.1, 2.1 and 3.1, which consist of zero cost interventions and in the two passive conditioning studied interventions (closing the shutters in summer and winter evenings), made a significant improvement in the results obtained in the heating demand between $33 \%$ and $50 \%$.

It is noted in figure 6 how activities 2.1, 2.2 and 2.3 imply an improvement in the heating demand, but a worsening in the cooling demand, compared to the activity 1.1, 1.2 and 1.3, respectively. The class schedule from 14:00 $\mathrm{h}$ to $21: 00 \mathrm{~h}$ improve the heating demand, but the cooling demand get worse compared to the schedule from 9:00 $\mathrm{h}$ to 16:00 $\mathrm{h}$.

To limit this negative behaviour in the cooling demand and since it is observed that this demand is mainly produce during September, we analyse the series of activities 3.1, 3.2 y 3.3, consisting in arranging the timetable from 14:00 $\mathrm{h}$ to $21: 00 \mathrm{~h}$ during the months of October to May and keep the current schedule from 7:00 to 14:00 during September.

Analysing the results obtained in the joint demand, which takes into account the heating and cooling demand effect simultaneously, as shown in Figure 7, it is appreciated that we have obtained improvements in all the options envisaged regarding the initial state.

Figure 7 also shows how if we perform only zero-investments interventions, each activity improves to the precious measure. This is how activity 3.1 improves activity 2.1, which at the same time exceeds activity 1.1. The same happens if we analyze the action which also envisages adequate measures of passive conduction. Activity 3.2 improves activity 2.2, which subsequently exceeds activity 1.2. Likewise, the activity 3.2 improves activity 2.2, which exceeds activity 1.2 . 
Figure 7. Results obtained in the joint demand in different activity. Source: Self elaboration.

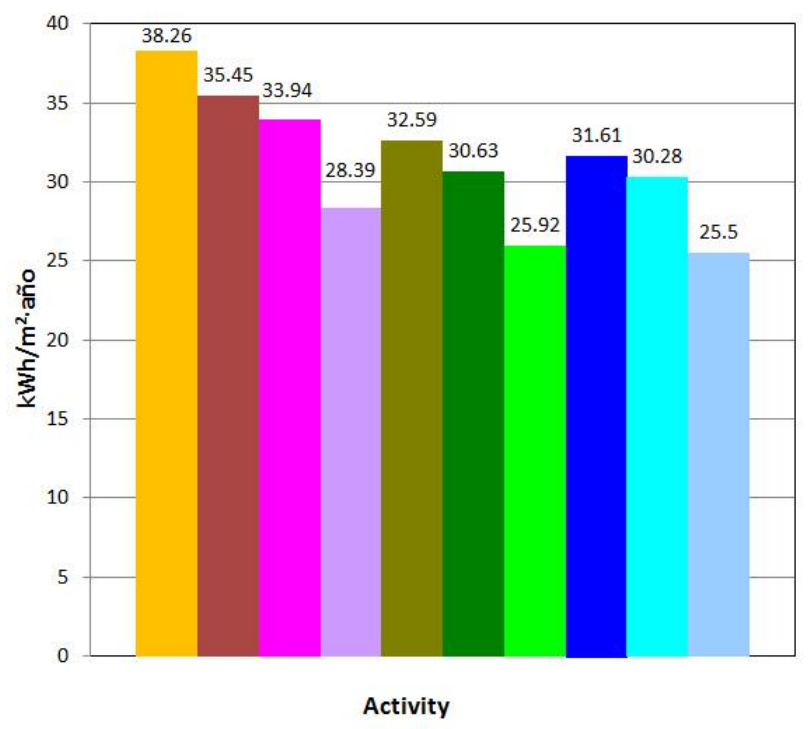

0. Classes from 7:00 to $14: 00$

1.1. Classes from $9: 00$ to $16: 00$

1.2. Close shutters on summer +1.1 .

1.3. Close shutters on winter nights +1.2 .

2.1. Classes from $14: 00$ to $21: 00$

2.2. Close shutters on summer +2.1 .

2.3. Close shutters on winter nights +2.2 .

3.1. Classes from 14:00 to $21: 00$ October-May

Classes from 7:00 to 14:00 September

- 3.2. Close shutters on summer +3.1 .

3.3. Close shutters on winter nights +3.2 .

The activity that presents a lower joint demand is the 3.3. It consists of arranging a timetable from 14:00 $\mathrm{h}$ to $21: 00 \mathrm{~h}$ during the months of October to May and from 7:00 h to 14:00 h during September lowering the shutters in summer and winter evenings.

The $€ 6,120$ of savings that are obtained annually with activity 3.3 could be an interesting economic injection that allows us to undertake future investments in the school centre, and, with it achieving the objectives sought with circular economy.

This way funds can be obtained to reduce the high cost or the return period of the energy rehabilitation works, which involve significant investments such as the modification of the window structure or the implementation of the insulation of the thermal envelope.

The final aim of the actions analysed is to promote energy rehabilitation so as to improve the well-being of the educational community. The objective of this process is to make students aware of the advantages of putting these energy and environmental actions into practice. This awareness will make it possible for the debate in these issues to move to the domestic area the debate and, why not, also to enable the development of some of this energetic action in their respective homes.

The proposed change of Schedule to the evening period, except in September that is maintained in the morning, together with the correct management of the shutters during summer and winter could be an attractive proposal for the directors of the educational centre because it allows new alternative self-financing pathways to come into being.

This ensures the development of circular economic premise and a sustainable manage, a care rational and efficient use of the planet's natural resources, a reduction of dependence on other non-sustainable resources, such as fossil energies and the creation of new economic opportunities. This would work out well for the long-terms competitiveness with other school centres.

It should be taken into account that the educational sector is and area very sensitive to variations in economic investments, especially in periods of crisis. This is why using alternative finance systems can be an interesting way to bear in mind in the economic politics of the school centres.

According to the precepts underlying the circular economic concept it would be possible to achieve considerable savings in reducing the energy bill and improvements in the comfort of the users of the building, which results in better school activity (Kelly et al., 2017; Sensharmaet al., 1998) and, finally, a reduction in greenhouse gas emissions. 
Amado, N. B., \& Sauer, I. L. (2012). An ecological economic interpretation of the Jevons effect. Ecological complexity, 9, 2-9.

Asociación Española de Normalización y Certificación. (2010). Comportamiento térmico de ventanas, puertas y persianas. Cálculo de la transmitancia térmica. Parte 1. Generalidades. UNE-EN ISO 10077-1. Madrid: AENOR, 2010.

Blanco, J. M., \& Peña, F. (2006). Obtención del Valor Real de las Pérdidas de Difícil Evaluación, Aplicables al Cálculo del Rendimiento de Calderas. Información tecnológica, 17(3), 123-128. http://dx.doi.org/10.4067/S0718-07642006000300018

de las Heras, B. P. (2016). La gestión eficiente de recursos en la Unión Europea: alcance e impacto de la normativa europea para una economía más sostenible y circular. Revista de Derecho Comunitario Europeo, 20(55), 781-817. doi: http://dx.doi.org/10. 18042/cepc/rdce.55.01

Díaz Sanchidrián, C., Díaz Chyla, A., \& Navacerrada Saturio, M. A. (2013). Estudio de los efectos acústico y térmico de la persiana integrada con la ventana. En Jornadas internacionales de investigación en construcción: vivienda: pasado, presente y futuro: resúmenes y actas. Instituto Eduardo Torroja. ISBN 978-84-7292-422-2.

EDP energía (2019). Retrieved from https://www.edpenergia.es/es/negocios/gas-y-electricidad/precios/ (Accessed: 5/12/2018).

European Commission (2018a). Paquete de medidas sobre clima y energía hasta 2020. Retrieved from https://ec.europa.eu/clima/policies/strategies/2020_es (Accessed: 28/11/2018).

European Commission (2018b). Marco sobre clima y energía para 2030. Retrieved from https://ec.europa.eu/clima/policies/strategies/2030_es (Accessed: 28/11/2018).

European Commission (2018c). The Energy Roadmap 2050. Retrieved from https://ec.europa.eu/energy/en/topics/energy-strategy-and-energyunion/2050-energy-strategy (Accessed: 28/11/2018).

European Commission (2014). Comunicación de la Comisión al Parlamento Europeo, al Consejo, al Comité Económico y Social Europeo y al Comité de las Regiones: Hacia una economía circular: un programa de cero residuos para Europa. Bruselas, 2.7.2014 COM 398. Retrieved from http://eur-lex.europa.eu/resource.html?uri=cellar:50edd1fd-01ec-11e4-831f-01aa75ed71a1.0009.02/DOC_1\&format=PDF

(Accessed: $7 / 12 / 2018)$

Gallego Sánchez-Torija, J. (2017). La auditoría energética operativa en centros docentes como herramienta para mejorar el ahorro y la eficiencia energética (Doctoral dissertation). Retrieved from: http://oa.upm.es/49548/1/JORGE_GALLEGO_SANCHEZ_TORIJA.pdf

Gallegos, D. P., \& Marín, L. M. (2018). Application of a grant in thermal reconditioning houses in the Metropolitan Region of Chile. Revista de la Construcción, $17(3), 401-411$.

García, S. G. (2018). Economía circular: 30 años del principio de desarrollo sostenible evolucionan en el nuevo gran objetivo medioambiental de la Unión Europea. Revista de estudios europeos, (71), 309-321.

Janda, K. B. (2011). Buildings don't use energy: people do. Architectural Science Review, 54(1), 15-22.

Kelly, M. T., Muñoz, J. S., San Martin, R. F., \& Piderit-Moreno, B. (2017). Metodología para el diseño de edificios educacionales confortables y resilientes. AUS [Arquitectura/Urbanismo/Sustentabilidad], (20), 70-76.

Lara, R. A., Pernigotto, G., Cappelletti, F., Romagnoni, P., \& Gasparella, A. (2015). Energy audit of schools by means of cluster analysis. Energy and Buildings, 95, 160-171. https://doi.org/10.1016/j.enbuild.2015.03.036

Larrumbide Gómez-Rubiera, E; Bedoya Frutos, C. (2015). El comportamiento del hueco de ventana en la arquitectura vernácula mediterránea antes las necesidades de acondicionamiento solar. Informes de la Construcción, 67(539), 120-130. ISSN-L: 0020-0883 doi: http://dx.doi.org/10.3989/ic.14.056.

Li, H., Bao, W., Xiu, C., Zhang, Y., \& Xu, H. (2010). Energy conservation and circular economy in China's process industries. Energy, 35(11), 42734281.

Mahdi, A. M. (2018). Energy Audit a step to effective Energy Management. International Journal of Trend in Research and Development, 5(2), 521525 ISSN: 2394-9333.

Ministerio de Energía, Turismo y Agenda Digital. (2018). Resolución de 22 de marzo de 2018, de la Dirección General de Política Energética y Minas, por la que se publica la tarifa de último recurso de gas natural. Boletín Oficial del Estado, 79, 1512-1515.

Ministerio de Fomento (2013). Orden FOM/1635/2013, de 10 de septiembre, por la que se actualiza el Documento Básico DB-HE «Ahorro de Energía», del Código Técnico de la Edificación, aprobado por Real Decreto 314/2006, de 17 de marzo. Boletín Oficial del Estado 219, 6713767209.

Ministerio de Industria, Energía y Turismo (2017). Herramienta Unificada Lider Calener. Retrieved from https://www.codigotecnico.org/index.php/menu-recursos/menu-aplicaciones/282-herramienta-unificada-lider-calener.html (Accessed: 4/12/2018).

Ministerio de Industria, Energía y Turismo (2016). Real Decreto 56/2016, de 12 de febrero, por el que se transpone la Directiva 2012/27/UE del Parlamento Europeo y del Consejo, de 25 de octubre de 2012, relativa a la eficiencia energética, en lo referente a auditorías energéticas, acreditación de proveedores de servicios y auditores energéticos y promoción de la eficiencia del suministro de energía. Boletín Oficial del Estado, 38, 11655-11681. 
Ministerio de Industria, Energía y Turismo, IDAE (2014). Guía técnica de prestaciones medias estacionales de las bombas de calor para producción de calor en los edificios. Retrieved from https://www.fempa.es/usuario/documentos/20161207131039_presta ciones-medias-estacionalesbombas-de-calor_IDAE.pdf (Accessed: 5/12/2018).

Pearce, D. \& Turner, R. (1990). Economics of natural resources and the environment. Baltimore: The Johns Hopkins University Press.

Pomponi, F., \& Moncaster, A. (2017). Circular economy for the built environment: A research framework. Journal of cleaner production, 143, 710718.

Rosa, E. A., Machlis, G. E., \& Keating, K. M. (1988). Energy and society. Annual review of sociology, 14(1), 149-172. https://doi.org/10.1146/annurev.so.14.080188.001053

Sensharma, N. P., Woods, J. E., \& Goodwin, A. K. (1998). Relationships between the indoor environment and productivity: a literature review. Ashrae Transactions, 104, 686.

Torralbo, A. C., \& Quijada, R. M. (2018). SIEM: Santiago (Chile) Integrated Energy Model. Revista de la Construcción, 17(3), $412-422$.

Unión Europea (2012). Directiva 2012/27/UE del Parlamento Europeo y del Consejo, de 25 de octubre de 2012, relativa a la eficiencia energética, por la que se modifican las Directivas 2009/125/CE y 2010/30/UE, y por la que se derogan las Directivas 2004/8/CE y 2006/32/CE. Texto pertinente a efectos del EEE. Diario Oficial de la Unión Europea, 315, 1-56.

Unión Europea (2018). Directiva (UE) 2018/851 del Parlamento Europeo y del Consejo de 30 de mayo de 2018, por la que se modifica la Directiva 2008/98/CE sobre residuos. Diario Oficial de la Unión Europea, 150, 109-140.

Valderrama, R. (2017). Reflexiones para un cambio de paradigma entre ser humano y medio a través de la educación socioambiental. Iberoamérica Social: Revista-red de Estudios Sociales VII, 37-39.

Zimring, C. M., \& Reizenstein, J. E. (1980). Post-occupancy evaluation: An overview. Environment and Behavior, 12(4), 429-450. 